\title{
Reseñas
}

Antonio García de León, Contra viento y marea. Los piratas en el Golfo de México, Plaza y Janés, México, 2004, 206 pp.

Como un marino avezado, Antonio García de León recorre las aguas del circuito atlántico-caribeño y en su derrotero arriba a los puertos del Golfo de México para ofrecernos esta otra cara de la piratería. No la de los feroces salteadores, hombres de pata de palo, parche en el ojo, orgullosos de enarbolar la bandera negra de la calavera y las tibias, sino la de la estrategia de debilitamiento que dispuso la moderna economía mundial. Se trata del relato acerca del "fenómeno terminal" de la piratería en el sistema de antiguo régimen.

Es, en palabras del autor, "una historia de vana obstrucción por el lado español y de fraude por el inglés, de bajeles que cargaban por la noche los almacenes de tierra y de buques escoltas, o bodegas secretas de los navíos permitidos, llenos de mercancías ilícitas" (p. 151). La tesis principal es que la piratería constituyó

el ariete inicial que fue abriendo de manera violenta la aceptación cada vez mayor del libre comercio y el fin de los monopolios, una actividad que se desarrolló paralelamente y en los márgenes del conflicto armado internacional de la época (p. 41).

Así, la ubica en la mundialización de los mercados. Con datos documentados ampliamente, se reconstruye la manera en la que el pillaje colaboró en desarrollar el comercio de los siglos coloniales y tejió las redes entre los espacios marítimos y los mercados interiores, así como entre las actividades legales de intercambio y el contrabando.

García de León despliega a sus personajes en el Gran Caribe, que es el Caribe geohistórico, más amplio que el geográfico, pero coloca su lente en el litoral del Golfo de México, específicamente en el arco comprendido entre Veracruz y Campeche, dos puertos que funcionaton como "centros" en las costas bajas del Seno Mexicano. Uno, del tráfico de Nueva España con la metrópoli y demás colonias del mundo caribeño, y el otro, del intercambio entre Yucatán, Nueva España y el resto del Caribe. En esta versión de los hechos, destacan dos elementos significativos: que estos piratas, comerciantes o contrabandistas, según la ocasión, establecieron lazos de complicidad o colaboración con los colonos, y que los emplazamientos piráticos "sirvieron de ayuda a la conformación definitiva de los mercados interiores de los puertos de Veracruz y Campeche" (p. 18).

El ensayo, como lo llama su autor, está dividido en tres capítulos: el primero se dedica a presentar el marco general, "el de la piratería como un fenómeno de interferencia que aparece en el cenit de la dominación del imperio colonial español 
en el nuevo mundo". Se examina la manera en que afectó al intercambio comercial del monopolio sevillano y cuál fue la percepción de los americanos que lo comparaban con el saqueo autorizado por la corona a sus súbditos peninsulares. Impresiona cómo se van destruyendo las estructuras monopolistas de Sevilla, comenzando en la misma Cádiz la "feroz competencia".

El segundo capítulo es un estudio de la piratería en el Golfo de México que resulta relevante, porque muestra cómo se construyeron los espacios de poder, la intrincada madeja de fraude, contrabando y piratería, los lazos de apoyo, la cultura del intercambio ilegal, y los mercados interiores, así como el papel "central" de los dos puertos ya mencionados, Veracruz y Campeche. Para García de León, el mismo año en que se desocupan definitivamente las bases piratas en el Seno Mexicano, "el mundo entró en una nueva etapa" (p. 76). Esta "coincidencia" se entiende mucho mejor cuando se toma en cuenta que el "Gran Caribe" era en realidad un conjunto de regiones, "compuesta de varias placas económicas y culturales", a saber: las Antillas Mayores y Menores, la Tierra Firme -en realidad el paso estratégico en el istmo-, más lo que los ingleses llamaban The Main, que se extendía del Darién a la actual Venezuela -con Cartagena de Indias-, continuaba hasta las islas Margarita y Trinidad, se conectaba con el arco que llega hasta Puerto Rico y, por el otro lado, incluía al Golfo de México. En el otro extremo, se encontraba el complejo Sevilla-Cádiz-islas Canarias, Madeira y Azores.

Finalmente, el tercer capítulo hace referencia a los principales aspectos de "la lenta y tardía respuesta militar del impe- rio" español, reflejo de su decadencia e impotencia. Se analiza esta respuesta en sus tres frentes, por demás onerosos e inútiles: las fortificaciones, la armada de barlovento y el corso; pero también, en este último capítulo, se muestra que la extinción de la piratería respondió a una serie de elementos que apuntaban a configurar un nuevo contexto mundial donde la piratería ya no respondía a las necesidades de este orden económico, no eran "útiles a sus intereses", y, de bravo y sangriento, el pirata pasó a convertirse en apacible colono y en ejemplo de "honorable y pacífico padre de familia".

A través de las páginas de este libro, escrito de manera clara y didáctica, el autor remonta viento y mareas, surca entre la historia oral y la amplia documentación de archivo resguardada en Europa y América, y, dándole la vuelta a la visión romántica de la piratería, rescribe la historia económica "a la luz de estas ideas", como imaginaba Keynes, refiriéndose a la consideración de que el botín de los piratas, de Drake en particular, podía ser tenido como "el origen y la fuente de las inversiones británicas en el extranjero" (p. 143). Además de esta nueva interpretación, el texto cuenta con apéndices y una bibliografía documental. Especialmente de mucha utilidad resulta el glosario de términos náuticos de la época. Desafortunadamente, no se puede decir lo mismo de los mapas. En un libro como éste, harían falta más mapas, acuciosos y con sus referencias completas. No obstante lo anterior, constituye una aportación importante al conocimiento de este lado del "Atlántico de Sevilla" y al sistema económico mundial, rescatando elementos que anteceden otras visiones como la ya clásica de Eric Williams. En esa medida es una 
referencia obligada, una lectura ineludible $y$, sin duda, de gran deleite.

\section{Laura Muñoz AMEC/INSTITUTO MORA}

Annick Lempérière, Entre Dieu et le Roi, la République. Mexico, XVe-XIXe siècles, Les Belles Lettres, París, 2004, 379 pp.

Annick Lempérière, en este trabajo, como ella misma lo indica, se

dedica a mostrar la concepción de "cuerpo político", la cultura pública, y las formas de gobierno que se desarrollaron en "México" mucho antes de que este país obtuviera su independencia y que alcanzara el régimen republicano (p. 11).

De esta forma su propuesta de análisis se centra en la caracterización de lo que llamaremos el sistema político virreinal o colonial, como un sistema de antiguo régimen, y que la autora denomina una "monarquía corporativa".

La autora destaca desde su introducción la rapidez y el éxito con que se multiplicaron las corporaciones en Nueva España; con este señalamiento propone superar el lugar que normalmente se da a las corporaciones, vistas tan sólo como una "categoría descriptiva de la historia social del antiguo régimen". Ella propone situarlas en el núcleo del sistema político imperante durante, por lo menos, los tres siglos de dominio español, puesto que considera su permanencia hasta el México contemporáneo. Pero su ambición va más allá, busca también borrar y deshacer las barreras que estableció la historiografía entre "religión" y "policía", y devolverles el significado y lugar que tuvieron en la construcción de una sociedad corporativa como la novohispana. Así, dedica la primera de las dos partes de su obra a caracterizar el sistema corporativo que se estableció en Nueva España desde la llegada de los primeros conquistadores con la creación de ayuntamientos, cofradías, universidades, gremios, hospitales; todo un mundo de corporaciones que cubrió literalmente el espacio político-religioso novohispano, y esto queda bien recalcado en la obra, la cual demuestra que no se puede entender el funcionamiento de la sociedad si separamos estos dos ámbitos.

La descripción de la república cristiana conforma la primera parte (pp. 23-131), compuesta por tres capítulos que tan sólo con los títulos nos permiten seguir el discurso de este trabajo: "El bien común y el buen gobierno", "El gobierno sin el Estado" y "El patriotismo republicano". En el primero explica el marco en que se unen el gobierno espiritual y el temporal, en este orden de importancia; toma como ejemplo la función que tienen las cofradías y hermandades en la realización del bien común. En el segundo expone cómo funciona eso en una sociedad donde el Estado no existe, y no existe porque el orden se mantiene en el interior de las corporaciones: la función del gobierno y de la cabeza de todas las corporaciones, el rey, es la de impartir justicia, de dar a cada quien lo que le corresponde, En el capítulo dedicado al patriotismo republicano, aborda el estudio de la capital del reino, la ciudad de México. Esclarece qué se entiende por esto y cómo el sentido de responsabilidad engendra actitudes solidarias en una sociedad organizada jerárquicamente.

En la segunda parte la autora se propuso revisar el impacto y los logros de las 